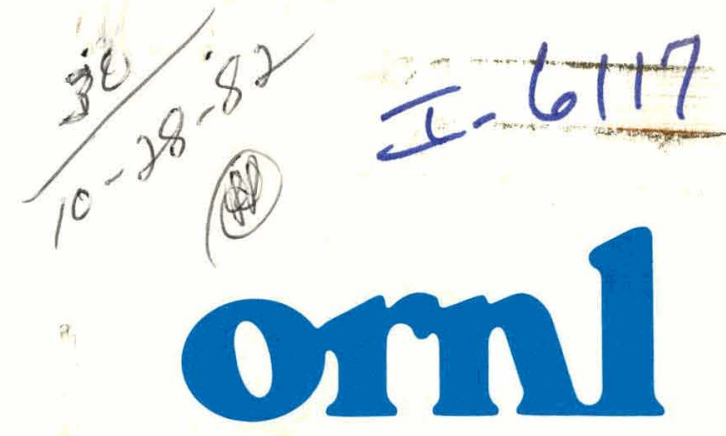

OAK RIDGE NATIONAL LABORATORY

UNION CARBIDE

\section{TSX-Plus for Laboratory Data Acquisition and Control}

\author{
J. M. Keller
}

OPERATED BY

UNION CARBIDE CORPORATION FOR THE UNITED STATES DEPARTMENT OF ENERGY 


\section{DISCLAIMER}

This report was prepared as an account of work sponsored by an agency of the United States Government. Neither the United States Government nor any agency Thereof, nor any of their employees, makes any warranty, express or implied, or assumes any legal liability or responsibility for the accuracy, completeness, or usefulness of any information, apparatus, product, or process disclosed, or represents that its use would not infringe privately owned rights. Reference herein to any specific commercial product, process, or service by trade name, trademark, manufacturer, or otherwise does not necessarily constitute or imply its endorsement, recommendation, or favoring by the United States Government or any agency thereof. The views and opinions of authors expressed herein do not necessarily state or reflect those of the United States Government or any agency thereof. 


\section{DISCLAIMER}

Portions of this document may be illegible in electronic image products. Images are produced from the best available original document. 
Printed in the United States of America. Available from National Technical Information Service

U.S. Department of Commerce

5285 Port Royal Road, Springfield, Virginia 22161

NTIS price codes-Printed Copy: A03; Microfiche A01

This report was prepared as an account of work sponsored by an agency of the United States Government. Neither the United States Government nor any agency thereof, nor any of their employees, makes any warranty, express or implied, or assumes any legal liability or responsibility for the accuracy, completeness, or usefulriess uf dily inlurriátioun, apparatus, produot, or process disconsed, nr represents that its use would not infringe privately owned rights. Reference herein to any specific commercial product, process, or service by trade name, trademark, manufacturer, or otherwise, does not necessarily constitute or imply its endorsement, recommendation, or favoring by the United States Government or any agency thereof. The views and opinions of authors expressed hercin do not necessarily state or reflect those of the United States Government or any agency thereof. 
Contract No. W-7405-eng-26

Analytical Chemistry Division

TSX-PLUS FOR LABORATORY DATA ACQUISITION AND CONTROL

J. M. Keller

Date Published - October 1982

\author{
OAK RIDGE NATIONAL LABORATORY \\ Oak Ridge, Tennessee 37830 \\ operated by \\ UNION CARBIDE CORPORATION \\ for the \\ DEPARTMENT OF ENERGY
}


THIS PAGE

\section{WAS INTENTIONALLY LEFT BLANK}




\title{
CONTENTS
}

\begin{abstract}
............................ 1 Introduction ......................... 1 Useful Routines for Data Acquisition and Instrument Control . . . . . 3 Accessing the I/O Page ................... . 3 Control of Program Swapping . . . . . . . . . . . . 7 Program Communication with TSX-Plus . . . . . . . . . . . 9 Detached Job Facility of TSX-Plus . . . . . . . . . . . 11 Interrupt Routines under TSX-Plus . . . . . . . . . . . . 13 Conclusion . . . . . . . . . . . . . . . . . . . . . . . . Appendix A. Subroutines for I/0 Page Access . . . . . . . . . . 19 Appendix B. Subroutines for Control of Program Swapping . . . . . . 26 Appendix C. Subroutines for Program Communications . . . . . . . 30 Appendix D. Subroutines for Support of the TSX-PIus Detached Job

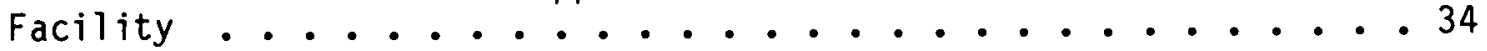


TSX-PLUS FOR LABORATORY DATA ACQUISITION AND CONTROL

J. M. Keller

ABSTRACT

TSX-PIus* is a multi-user operating system for PDP-11t and LSI-11t computers, which offers many of the features available with the DEC RSX-11M.t For present users of RT-11t who wish to upgrade to a multi-user operating system, TSX-Plus offers several advantages over RSX-11M, such as lower cost and software compatibility with RT-11. TSX-Plus maintains a similarity with RT-11 by employing the RT-11 utility programs and device drivers; also, the RT-11 monitor commands are a subset of the TSX-Plus commands. Laboratory applications of TSX-Plus are discussed, and a set of FORTRAN callable subroutines, which are useful for data acquisition and hardware control, are presented. Also, the use of hardware interrupt and trap instructions (software interrupt) under TSX-Plus are discussed.

\section{INTRODUCTION}

TSX-Plus is a general purpose, time-sharing operating system for Digital Equipment Corporation (DEC) PDP-11 and LSI-11 computers. TSX-Plus will run on any PDP-11 or LSI-11 computer that has memory management facilities and at least 96 kbytes of memory. The functionality of the DEC RT-11 operating system is retained under TSX-Plus for up to twenty concurrent timesharing users. However, TSX-PIus is not an RT-11 emulator; rather, TSX-Plus supports RT-11 service calls as its basic mode of operation. TSX-Plus interfaces with standard RT-11 device handlers, supports RT-11 utility programs (i.e., PIP, DUP, DIR, etc.) and CCL commands (i.e., COMPILE, EXECUTE, etc.), and provides a super set of RT-11 keyboard commands. In general, it will appear to a user under TSX-Plus, that. an RT-11 single job monitor is operating.

*Available from S\&H Computers, Nashville, TN (615/327-3670). tTrademark of Digital Equipment Corp. (DEC). 
A time-sharing system is a multiprogrammed computer that allows its multiple users to share system resources in such a fashion that each user thinks he is getting individual attention. The system is multiprogramed in that several user programs (or jobs) may reside concurrently in memory at any given time. Each program receives a quantum of computer time, called a time slice, during which it can perform computations. Should the job use up its time slice or reach a point where further computations are not possible (i.e., I/0 information is needed), the CPU will be turned over to another program. This transfer is handled rapidly since the next program to gain access to the CPU will already be in memory.

The time-shared operation of a computer implies sharing the computer's time and space resources on a dynamic, and hence temporary, basis. Several user programs may be memory resident while others may be in the process of being loaded from or to auxiliary mass storage. If memory is not large enough to hold all the user programs or jobs and data (which is usually the case), it will be necessary to swap user information in and out from the auxiliary storage upon demand. The swapping requirement implies the use of a high-speed mass storage device, the minimum of which is a floppy disk system. However, it is preferable to employ mass storage that is faster and has a larger storage capacity than a floppy disk. The DEC RL01 or RL02 system or one of the newer Winchester disk systems is an example of mass storage that is more suitable for the swapping requirements.

Another feature of the TSX-Plus is its ability to handle real-time programming, which is a necessity for applications involving hardware control and data acquisition. Real-time systems are designed for handling data in a time that is consistent with the response time demanded by the process that generates the information. Such systems operate in a multiprogrammed environment with a real-time monitor controlling and supervising a large number of memory- or disk-resident proyrams and tasks. This supervision allows the tasks to share memory and disk space, I/0 device handlers, and resource allocation and use. The execution of the many tasks is determined by software priorities, hardware intérrupts, timing algorithms, and requests from other tasks.

TSX-Plus offers the option of requiring users to $\log$ on the system. The log-on feature allows the system manager to allocate account numbers and 
pass words to the system users. This not only gives the system manager the option of monitoring system use but also provides a degree of security to the system. For the protection of system software and critical data, the access to mass storage devices and other system resources can be limited. The degree of access to the system is controlled by the system manager and is based upon the user's account number. System access can also be based upon the terminal or line number used for communication with the system. This feature is useful in preventing novice users from damaging system software by locking a user to a specific application program and in preventing an experienced user from inadvertently disrupting instrument control or data acquisition by accessing the I/0 page.

The purpose of this paper is to present a set of routines that employ a subset of the available EMTs under TSX-Plus that will allow a FORTRAN programmer with the facilities to control and read data from the real world. Also, several routines that support the message communication facilities between jobs and the detached job facility are presented. The routines will provide the TSX-Plus user with examples of employing the EMT routines, a feature that is lacking in the TSX-Plus documentation. A knowledge of FORTRAN and a basic understanding of RT-11 are assumed for the following discussions.

USEFUL ROUTINES FOR DATA ACQUISITION AND INSTRUMENT CONTROL

Data acquisition and instrument control require access to the device status and control registers that reside in the I/0 page (address 160000177777 ) on PDP-11 and LSI-11 computers. A normal TSX-Plus time-sharing job cannot access the I/O page; however, TSX-Plus provides the facilities necessary to read and write to this area. By providing a number of emulator trap (EMT) service routines, TSX-Plus not only allows the MACRO-11 programmer to access the I/0 page but also provides many useful facilities for program design and development.

\section{ACCESSING THE I/O PAGE}

Six routines (all FORTRAN callable) that allow the programmer access to the I/0 page are presented. A source listing of these routines is provided 
in Appendix $A$ and includes the routines BITCLR, BITSET, IOPEEK, IOPOKE, MAPIO, and UNMAP. These routines are coded in MACRO-11 and can be called by either a FORTRAN or another MACRO-11 program.

One can access the I/O page with a program executing under TSX-Plus in two ways. The efficient technique is to access the device control registers directly by mapping the $I / 0$ page to the program's virtual address region (160000-177777). A call to the routine MAPIO performs this function for either the FORTRAN or MACRO programmer. With the I/O page mapped to the user's area standard RT-11 system library routines, IPEEK and IPOKE can be employed by the FORTRAN programmer to access device control registers, and the MACRO programmer can employ standard techniques to access these registers. The complement to the MAPIO routine is the UNMAP routine. The UNMAP routine will map the program's virtual address region (160000-177777) to the simulated resident monitor (RMON) - default status for the TSX-Plus program.

If a TSX-Plus program requires access to offsets inside the RMON, the MAPIO routine cannot be employed. For this case, TSX-Plus provides EMTs to peak. poke, bit-set, and bit-clear registers in the $I / 0$ page.

The subroutines IOPEEK and IOPOKE allow a prugiam to access the I/O page without requiring the job's virtual address region to be mapped to the I/O page. To a FORTRAN programmer, the function and calling format for IOPEEK and IOPOKE is identical to the RT-11 system library subroutines IPEEK and IPOKE. The IOPEEK subroutine allows a program to read the contents of a word in the I/O paqe. The FORTRAN call format is

$$
I=\operatorname{IOPEEK} \text { (address) }
$$

or

$$
\text { CALL IOPEEK (address, I), }
$$

where address is the actual octal address in virtual memory to be read, and the contents of this address are returned in the integer variable $I$. 
The IOPOKE subroutine permits a program to write data into a memory cell within the $1 / 0$ page. The FORTRAN call format is

$$
\text { CALL IOPOKE (address, value), }
$$

where address is the octal location that the contents of value will be stored. An example of employing IOPEEK and IOPOKE is presented in Program 1.

\section{Program 1}

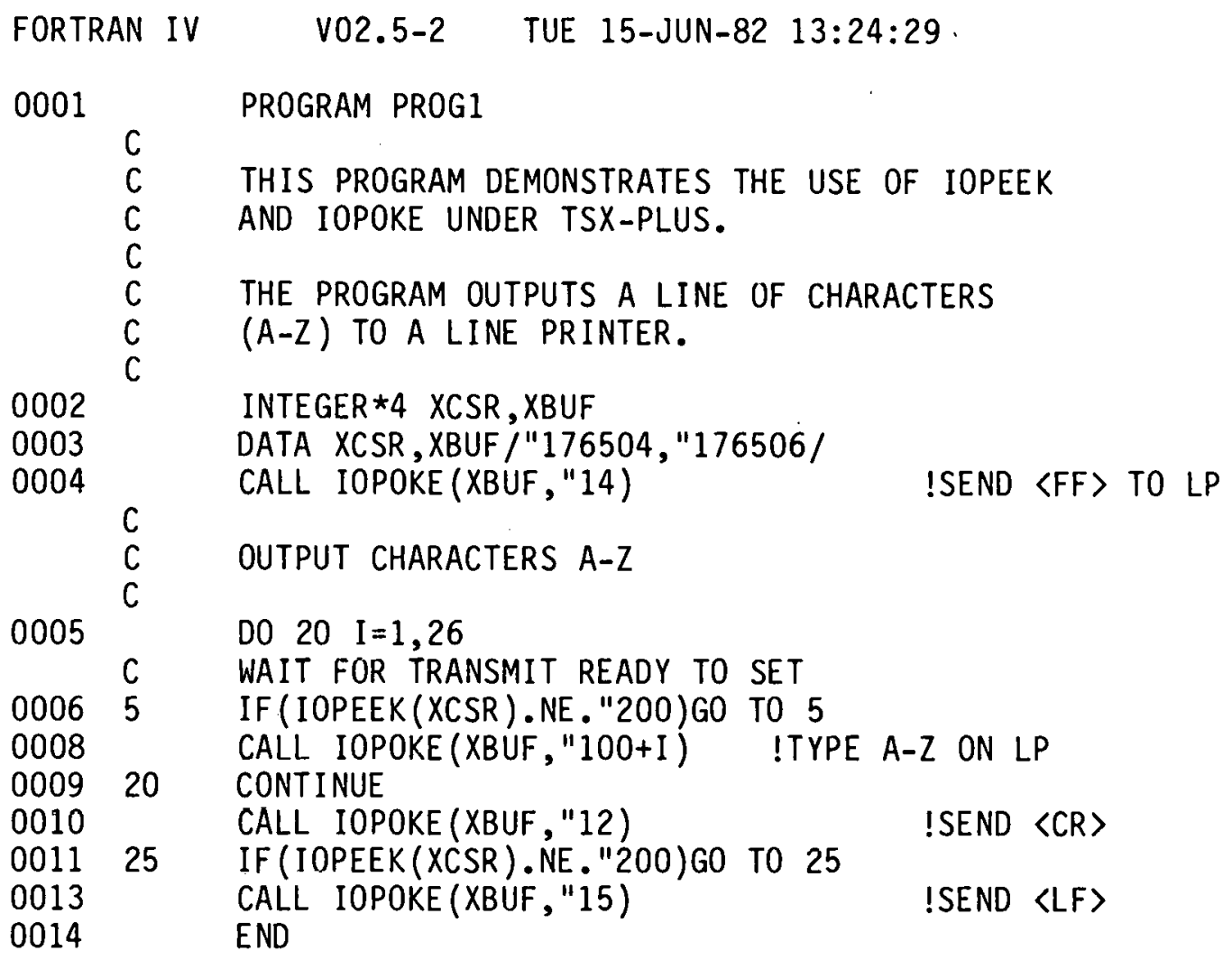

Program 1 outputs a line feed (octal 14, line 4), the characters A-Z (line 5-9), and a carriage return (1ine 10) to a line printer. The octal address in the I/0 page for the line printer's transmit status register and buffer is defined in line 3. Line 6 is present to make sure the last character transmitted to the line printer is received before the next character is transmitted by doing an IOPEEK at the line printer status register and waiting until the transmit ready bit is set. 
The subroutines BITCLR and BITSET also provide the means for a programmer to access the I/O page. The BITCLR allows one to clear various bits within the contents of an address. The FORTRAN call format is

\section{CALL BITCLR (address, value),}

where address is the octal address in the $1 / 0$ page to which the bits defined by the argument value will be cleared (set to zero).

The subroutine BITSET is the compliment to BITCLR and allows the programmer to set various bits within the contents of an address in the $I / 0$ page. The FORTRAN call format is

\section{CALL BITSET (address, value),}

where address is the octal address in the $I / 0$ page to which the bits defined by value will be set (set to one). An example of employing BITSET is given in Program 2.

\section{Program 2}

FORTRAN IV V02.5-2 TUE 15-JUN-82 13:24:29

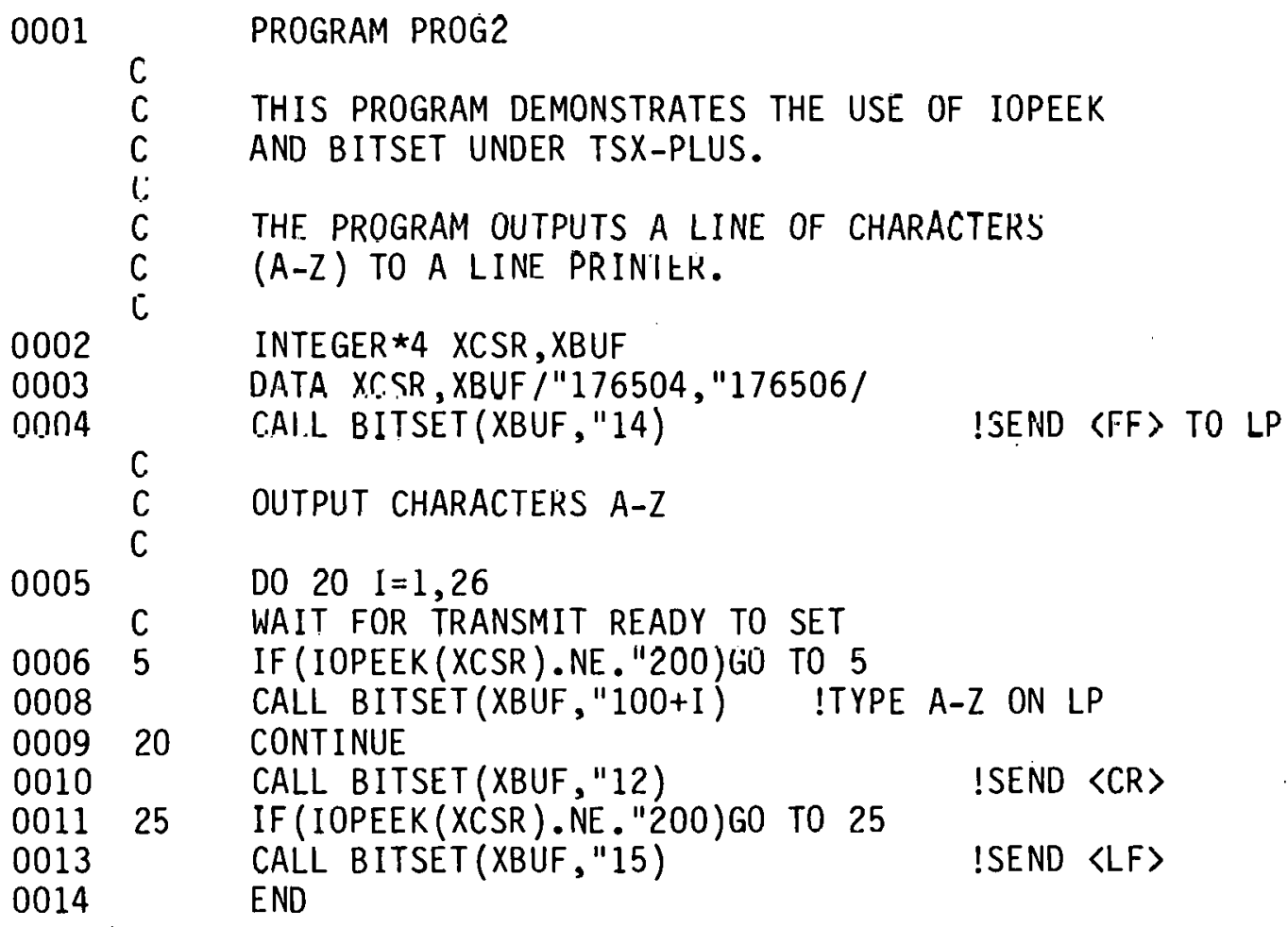


Program 2 is identical to Program 1 except that the IOPOKE has been replaced with a call to BITSET at lines $4,8,10$, and 13 .

Although it appears that IOPOKE and BITSET perform the same function, they are different. If an IOPOKE is executed, the contents of the address are replaced by the subroutine argument. Consider the following FORTRAN code:

$$
\begin{aligned}
& \text { CALL IOPOKE ("176000," 200) } \\
& \text { CALL IOPOKE ("176000,"10) } \\
& \text { I = IOPEEK ("176000) }
\end{aligned}
$$

The value of "I" would equal octal 10. If a BITSET is executed, only the bits defined by the BITSET argument are changed:

$$
\begin{aligned}
& \text { CALL. IOPOKE ("176000,"200) } \\
& \text { CALL BITSET ("176000,"10) } \\
& \text { I = IOPEEK ("176000) }
\end{aligned}
$$

The value of "I" would equal octal 210.

Since the BITSET routine changes only the bits defined by the argument, one might ask why example Program 2 works the same as Program 1. Output to the transmit buffer of the serial interface employed for this example is a special case. When one writes a value to the transmit buffer (XBUF), the character represented by the octal value is output to the line printer. Once the character is printed, the transmit buffer is empty or equal to zero. In other words, the transmit buffer has no memory of its previous contents since it is always equal to zero after the character is printed.

\section{CONTROL OF PROGRAM SWAPPING}

TSX-Plus is a multi-user system, which implies that a number of programs may be memory resident concurrently. If the memory required by the programs exceeds the available memory, it is necessary to swap programs between memory and disk. In time-critical applications, where a program must respond to an interrupt in real-time, it may be necessary for the 
routines to be locked into memory to avoid swapping. When a program is locked into memory, the space occupied by the program is no longer available for the multi-user environment; therefore, care should be exercised when lock.ing large programs into memory

TSX-PIUs provides two EMT facilities for locking a program into memory. The two FORTRAN callable routines, which employ the EMTs, are listed in Appendix B. The first subroutine LOCKLO will move the program to the low end of memory before locking it. This transfer to low memory is performed so that the available free memory is not fragmented. The FORTRAN call format is

\section{CALL LOCKLO}

and is normally employed when a program will be locked in memory for a long period of time. Since the LOCKLO routine may involve program swapping, it can be a relatively slow form of locking.

The second subroutine for locking a program into memory is JLOCK, which has a FORTRAN call format of

\section{CALL JLOCK •}

The JLOCK subroutine simply' locks the program into the memory space that is occupied when the EMT is executed. This form of program locking has the advantage of being extremely fast, since no program swapping is required; however, the free memory space may be noncontiguous. The subroutine JLOCK should be employed only for applications that require the program to be locked for a relatively short period of time.

A third EMT for control of program swapping provided by TSX-PIus allows one to unlock a program from memory. This EMT is available to the FORTRAN programmer through the subroutine UNLOCK; the FORTRAN call format is

\section{CALL UNLOCK :}

When a program is locked into memory, it will remain locked until the program ends or the unlock EMT is executed. 
PROGRAM COMMUNICATION WITH TSX-PLUS

TSX-Plus provides a useful facility that allows running programs to communicate with each other via named message channels. Three EMTs are provided to support the message communication facility for the assembly language programmer. Included in Appendix $C$ are corresponding FORTRAN callable subroutines for each EMT.

A message channel accepts a message from a sending program, stores the message in a queue associated with the channel, and delivers the message to a receiving program that requests a message from the channel. Associated with each active message channel is a one-to-six character name that is used by the sending and receiving programs to identify the channel. Once a message is queued on a channel, that message will remain in the queue until some program receives it or until the TSX-Plus system is restarted. This allows a program to leave a message for another program that will run later.

To put a message on a named channel, the subroutine MSEND is employed. FORTRAN call format is

\section{CALL MSEND (chan. name, message),}

where chan. name is a one-to-six character name for the message channel to be employed and the message is a one-to-sixty-four-byte ASCII string. If other messages are already pending on the channel, the new message is added to the end of the list of waiting messages. The sending program does not wait for the message to be accepted by a receiving program, and since the message is saved in an internal buffer, the sending program is free to destroy its message on completion of the subroutine.

Two routines are available for receiving messages from a named message channel. The first routine is MRECV; the FORTRAN call format is

$$
\text { CALL MRECV (chan. name, iarray, IFLAG) }
$$

or

$$
\text { IFLAG = MRECV (chan. name, iarray), }
$$


where chan. name is the message channel to check for a pending message, iarray is a 64-byte array to receive the message, and IFLAG is the message status flag (IFLAG $=1$ if message was received, IFLAG $=0$ if no message is pending). If no message is pending, IFLAG is cleared and the program is allowed to continue execution.

The second routine for receiving messages is MRECVW, and the FORTRAN call format is

\section{CALL MRECVW (chan. name, iarray),}

where chan. name and iarray are defined the same as for MRECV. The main difference in this message-receiving routinc and the previnus one is that the MRECVW will suspend program execution until a message becomes available uri a named channel.

An example of employing the message communication facility of TSX-Plus is presented in Program 3 and Program 4.

\section{Program 3}

FORTRAN IV V02.5-2 TUE 15-JUN-82 13:24:36

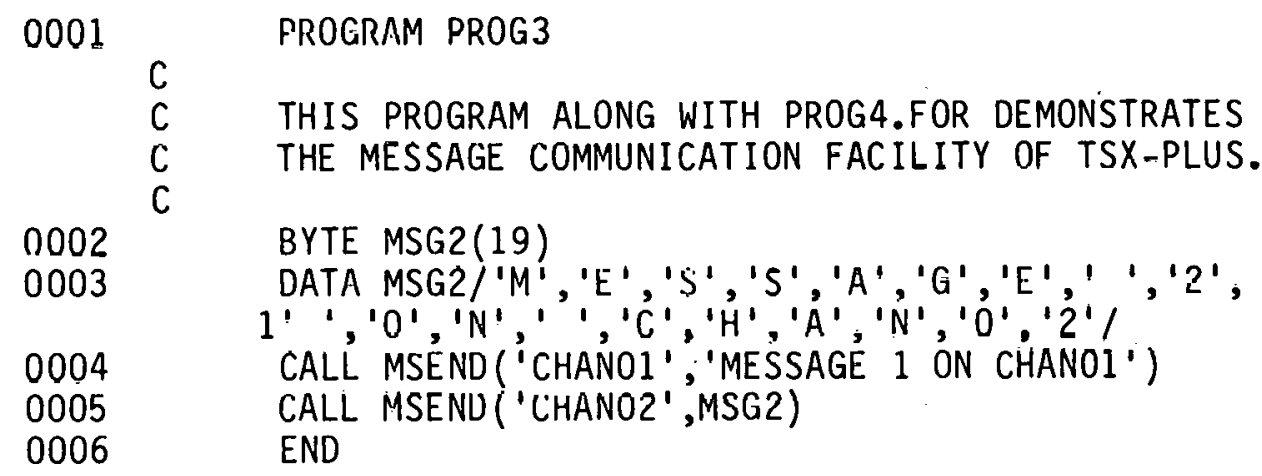

Program 4

FORTRAN IV V02.5-2 TUE 15-JUN-82 13:24:39

$0001 \quad$ PROGRAM PROG4

C THIS PROGRAM RECEIVES TWO MESSAGES FROM THE

C PROGRAM PROG3. SEVERAL FORMS OF THE RECEIVE

C MESSAGE SUBROUTINES ARE DEMONSTRATED. 
Program 4 (continued)

\begin{tabular}{|c|c|c|}
\hline 0002 & $r$ & BYTE ARRAY (64) \\
\hline & $\begin{array}{l}\mathrm{C} \\
\mathrm{C} \\
\mathrm{C}\end{array}$ & $\begin{array}{l}\text { THIS CALL SUSPENDS PROGRAM EXECUTION UNTIL } \\
\text { THE MESSAGE IS RECEIVED. }\end{array}$ \\
\hline $\begin{array}{l}0003 \\
0004\end{array}$ & & $\begin{array}{l}\text { CALL MRECVW ('CHANO1', ARRAY) } \\
\text { CALL PUTSTR ( } 7, \text { ARRAY, 'O', IERR) }\end{array}$ \\
\hline & $\begin{array}{l}C \\
C \\
C \\
C \\
C \\
C \\
C \\
C\end{array}$ & $\begin{array}{l}\text { THIS CALL WILL NOT SUSPEND EXECUTION. IF THE } \\
\text { VALUE OF IFLAG=1 A MESSAGE WAS RECEIVED, IF } \\
\text { IFLAG=0 NO MESSAGE WAS QUEUED ON THE NAMED } \\
\text { CHANNEL. THIS SUBROUTINE CAN ALSO BE CALLED AS } \\
\text { A FUNCTION SUBROUTINE E.G., } \\
\text { IFLAG=MRECV ('CHANO2', ARRAY) }\end{array}$ \\
\hline $\begin{array}{l}0005 \\
0006 \\
0007\end{array}$ & & $\begin{array}{l}\text { CALL MRECV ('CHAN02', ARRAY, IFLAG) } \\
\text { CALL PUTSTR ( } 7, \text { ARRAY, ' } 0 \text { ', IERR) } \\
\text { END }\end{array}$ \\
\hline
\end{tabular}

When Program 3 is executed, two messages are placed on the named channel: "CHANO1" and "CHAN02." These two messages will remain queued until Program 4 is run. When Program 4 is executed, the two messages are removed from the queue and printed at the user's terminal.

\section{DETACHED JOB FACILITY OF TSX-PLUS}

Detached jobs operate similarly to a "batch" facility: generally, input to a detached job comes from a command file. However, a detached job can send and receive data via the message communication facility of TSXPlus. The detached job facility of TSX-Plus allows the time-sharing user to initiate execution of several simultaneously executing jobs. Although the DETACH keyboard command can be used to start a detached job, an EMT is also provided to allow an executing program to start a detached job. The FORTRAN callable subroutine IDTACH is listed in Appendix D, and the FORTRAN call format is

CALL IDTACH (file name, job)

or

$$
J O B=\operatorname{IDTACH} \text { (file name), }
$$


where file name is a command file that starts the detached job, and job is an integer variable in which the job number assigned to the detach job is returned. Care should be employed in defining the file name because the subroutine does not allow the use of logical device assignments. For example,

$$
J O B=\text { IDTACH ('DYO: FILNAM.EXT') }
$$

is acceptable; however, 'DK:FILNAM.EXT' would not execute correctly. The default file extension is .COM.

A running detached job may be aborted by calling the subroutine KILL. The subroutine KILL is listed in Appendix D, and the FORTRAN call format is

\section{CALL KILL (job),}

where job is the job number obtained from the call to IDTACH. Programs 5 and 6 demonstrate the use of the subroutine IDTACH.

\section{Program 5}

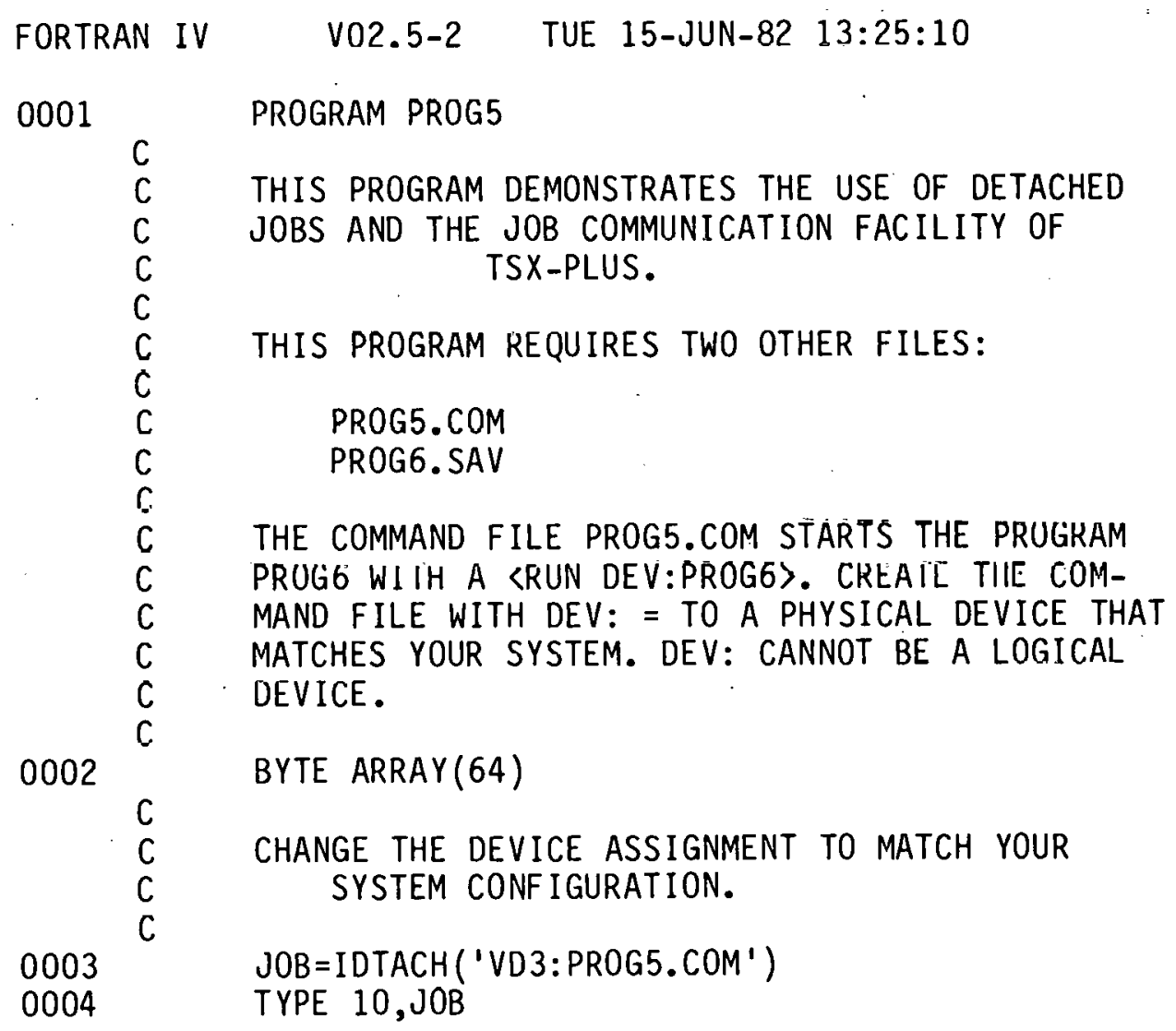


Program 5 (continued)

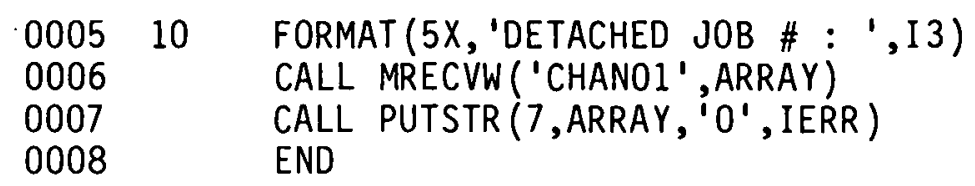

\section{Program 6}

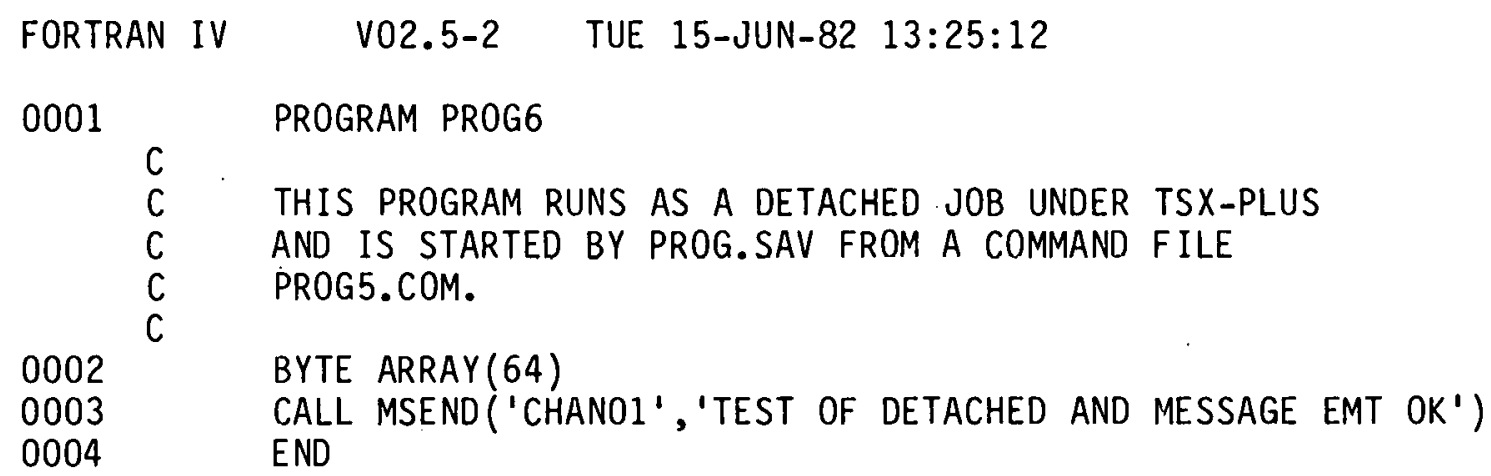

\section{INTERRUPT ROUTINES UNDER TSX-PLUS}

The TSX-Plus real-time support facility provides the means for processing hardware interrupts and trap instructions. The development of interrupt-driven completion routines under TSX-Plus is somewhat different than for RT-11 in that the. INTEN, .PROTECT, and .SYNCH programmed requests are not employed. Also, the RTI (return from interrupt) employed with RT-11 is replaced with an RTS PC (return from subroutine). A TSX-Plus EMT is provided for connecting a completion routine to a hardware interrupt or trap instruction. The EMT allows one to load the address of the completion routine in the interrupt vector address and assign a priority to the interrupt.

The interrupt priority assigned to a completion routine is used by TSXPlus to schedule the routine for execution. The available priority levels are 0 to 7 . The 0 priority is a special case in that conditions for timesharing between jobs continues to take place. When employing priorities greater than 0 , an executing completion routine will lock out all timesharing users until the processing is complete or a system wait state is encountered. In a system wait state, such as waiting for the completion of an I/0 operation, the completion routine losses its high priority and will subsequently run as a normal time-sharing job. When employing interrupt 
routines under TSX-Plus, the programmer must keep in mind that a higher priority completion routine for one job will interrupt only a lower priority completion routine being executed by another job. A higher priority completion routine will not interrupt a lower priority completion routine for the same job.

An example of employing hardware interrupts is presented in Program 7.

Program 7

TITLE WAITFO

ROUTINE TO WAIT A SPECIFIED TIME

FORTIR.AN C:ALI FORMAT:

CALL WAITM(COUNT) MILLISECONDS

OR

CALL WAITS(CUUNI) SECONDS

MACRO CALL FORMAT:

MSEC: $\quad$ MOV COUNT,R1

JSR PC, MWAIT

SFC: $\quad$ MOV : COUNT, R1

USR PC,SWAIT

.MCALL .DEVICE, . SPND, . RSUM

SPECIFY ADDRESS AND VECTOR FOR KW1IP CLOCK

KC.SR $=172540 \quad$;CLOCK CSR

$K B U F=K C S R+2 \quad$;COUNTER LOAD/PRESËT BUFFER

KCTR $=K C S R+4 \quad$;COUNTER READ REGISTER

KVEC $=104 \quad$;CLOCK INTERRUPT VECTOR

WAITM:: MOV $22(R 5), R 1 \quad$;GET CLOCK COUNTS

MWAIT:: MUL \#10.,R1 ;MULT. COUNTS BY 10

MOV RI, Q\#KBUF ;LUAU CLLOCK COUNTER

MUV H1O3,R3 ;SET CLK: TO $10 \mathrm{MHZ}$

BR SETUP

WAITS: : MOV O2(R5),R1 ;GET CLOCK COUNTS

SWAIT:: MUL \#60.,R1 ;MULT. COUNTS BY 60

MOV R1, @\#KBUF ;LOAD CLOCK COUNTER

MOV \#105,R33 ;SET CLK TO $60 \mathrm{HZ}$

SETUP: MOV \#AREA,RO ;SETUP INTERRUPT VECTOR

EMT $\quad 375$

.DEVICE \#AREA1, \#ADDR ;CLEAR INTERRUPT IN CASE OF ABORT

MOV R3, Q\#KCSR ;ENABLE INTERRUPT 
Program 7 (continued)

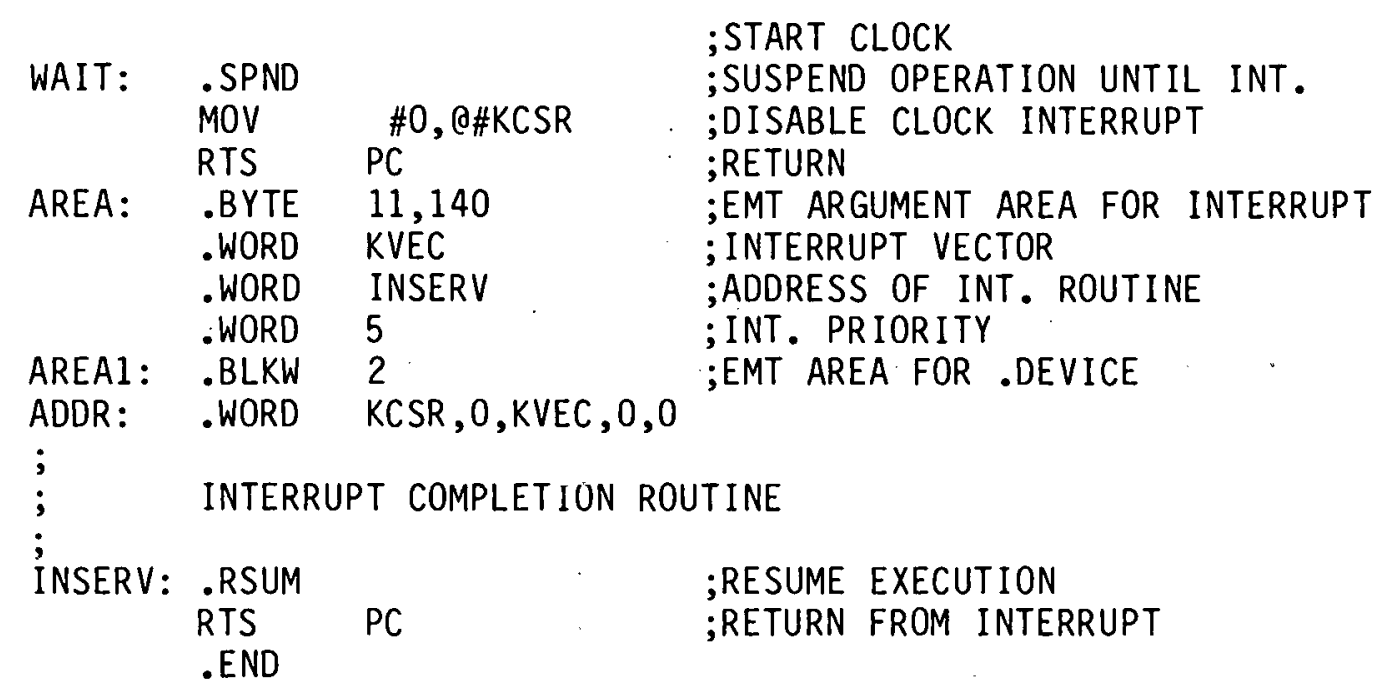

Program 7 is a FORTRAN callable subroutine that employs the KW11P programmable real-time clock to provide accurately timed delays under TSX-Plus. The units of time for a delay may be either milliseconds or seconds, depending upon the global entry label used by the FORTRAN call. The FORTRAN call format is

\section{CALL WAITM (count)}

for a millisecond delay and

\section{CNLL WAITS (count)}

for a second delay. The argument count is the number of specified time units to suspend program execution. Because of the time-slicing environment of TSX-Plus, the minimum delay that can be used for WAITM is approximately 20 milliseconds. Part of the reason for this relatively large minimum delay time is due to TSX-Plus service routine for the line time clock. The linetime clock interrupts the system every $1 / 60$ of a second. The TSX-Plus completion routine for the line-time clock must not only update the system time and date but also handle the allocation of a time-slice to a time-sharing user. The extra code that. is required by the line-time clock service 
routine under TSX-Plus results in a decrease in program speed when compared with RT-11. Also, the line-time clock service routine may create problems for time-critical applications that are not connected to a completion routine.

Since a trap instruction is effectively an interrupt generated by software and it is handled in the same manner as a hardware interrupt under TSX-Plus, several trap instructions that are vectored at different locations are available to the MACRO-11 programmer. The available instructions include BPT (break-point trap, vector $=148)$, IOT ( $1 / 0$ trap, vector = 208), EMT (emulator trap, vector $=30_{8}$ ), and TRAP (vector $=348$ ). The EMT trap instruction is employed extensively by both RT-11 and TSX-Plus; therefore, general use of the EMT instruction is not recommended. The TRAP instruction is used by FORTRAN for error processing and should not be employed by programs linked to FORTRAN routines. Although the BPT and IOT instructions are available for general use, the BPT instruction should be avoided if one of the debugging aids is employed. An example of using a break-point trap instruction under TSX-PIus is provided in Program 8.

ProyrdIII 0

-TITLE PRUGष̈.MAT.

; $\quad$ PROGRAM TO DEMONSTRATE THE USE OF A

; TRAP INSTRUCTION UNDER TSX-PLUS

PROG8:

.MCALL .PRINT, . EXIT

MOV \#AREA, KO OSET UP INTERRUPT

EMT $\quad 375$

.PRINT \#MESS 1

BPT

.PRINT \#MESS2

EXIT

;EXECIJTE TRAP INSTRUCTION

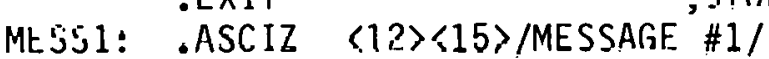

MESS2: .ASCIZ $\langle 12\rangle\langle 15\rangle / M E S S A G E \# 2 /$

MESS3: .ASCIZ $\langle 12\rangle\langle 15\rangle /$ MESSAGE \#3/

.EVEN

ARGUMENT AREA FOR INTERRUPT EMT

AREA: .BYTE 11,140

- WORD 14

-WORD INT

;BPT VECTOR

.WORD 1

;ADDRESS OF COMPLETION ROUTINE

;PRIORITY 
Program 8 (continued)

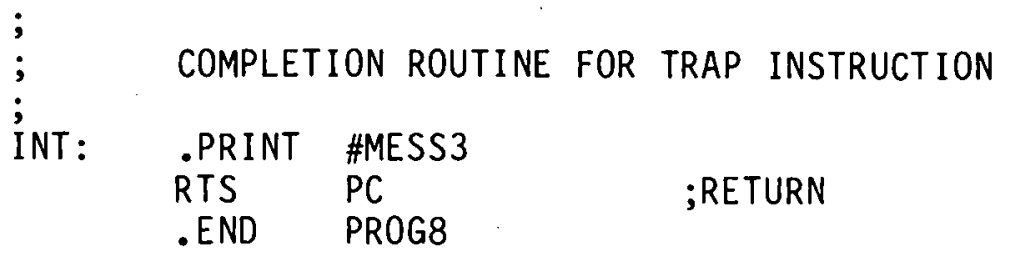

The execution of Program 8 results in the output of three lines of text to the user's terminal,

\author{
MESSAGE \# 1 \\ MESSAGE \#3 \\ MESSAGE \#2
}

The second line of output (MESSAGE \#3) is a result of the BPT instruction. Although the trap instruction is rarely employed by most programmers, it is a valuable asset in a time-sharing environment. For laboratory applications involving control of instrumentation, there may be times when an error condition requires immediate attention. Some control applications require a section of code that cannot tolerate the time-slicing state of TSX-Plus. Both of the examples are problems for which a trap instruction may provide a solution by locking out time-sharing users until the trap service routine is completed.

A final point for discussion concerning hardware interrupts and trap instructions is the use of FORTRAN completion routines. A FORTRAN subroutine can be attached to a trap instruction (BPT or IOT) or a hardware interrupt by including in the first line of the MACR0-11 completion routine the instruction

JSR PC, FILNAM,

where FILNAM is the name of the FORTRAN subroutine. Do not use the RT-11 system library routine INTSET to establish a FORTRAN subroutine as an interrupt completion routine. 


\section{CONCLUSION}

TSX-Plus is an attractive alternative to DEC's RSX-11M, especially for present users of RT-11, since upgrade to a multi-user system with TSX-Plus could be achieved at a fraction of the cost for RSX-11M. Also, most programs developed under RT-11 are transportable to TSX-Plus with little or no modifications. One final advantage of TSX-Plus is that implementation of the operating system is simple and much less involved than a system generation for RSX-11M. For most cases with TSX-Plus, the system generation options can be modified, and a new system compiled and linked in a matter of minutes.

General use of RT-11 for instrument control and data acquisition effectively dedicates the computer to the instrument. Employing a multi-user system for laboratory applications provides a much more efficient use of system resources. A multi-user system, such as TSX-Plus, allows one to concurrently control multiple instruments and use system resources for software development.

Applications involving simultaneous control of several instruments may require a modular computer configuration. Such a computer system would consist of a main computer operating under a multi-user environment with a satellite microcomputer dedicated to each instrument for control and data acquisition. The main computer could then serve as the supervisor in a local network of several computers. The supervisor computer would send commands to and receive data from satellite processors and in addition would handle all calculations, file and data management, and data reporting. With this type of laboratory computer system, the concurrent execution of many time critical routines could operate without conflict. In addition to the instrument control aspect, laboratory personnel would also have access to the computer for general use.

In conclusion, TSX-Plus can be employed in a multifunction laboratory environment and meet most required functions for instrument control, data acquisition, and data management. A good starter system for a laboratory, which could be easily expanded, would include a DEC LSI-11/23 with 22-bit addressing memory management, 256-kbyte memory, and a 10-30 Mbyte Winchester disk for mass storage. Two good choices for the satellite microcomputers are the Rockwe 11 AIM-65 and the new DEC FALCON SBC-11/21. 
Appendix A. Subroutines for $1 / 0$ page access

\author{
BITCLR \\ BITSET \\ IOPEEK \\ IOPOKE \\ MAPIO \\ UNMAP
}




\section{.TITLE BITCLR}

SUBROUTINE TO CLEAR BITS FROM A FORTRAN

PROGRAM UNDER TSX-PLUS.

FORTRAN CALL :

CALL BITCLR (ADDRESS, VALUE)

.MCALL .PRINT, . GVAL

.GLOBL BITCLR

OFFSET $=-10$

BITCLR: TST

MOV

MOV

.GVAL

CMP

$(\mathrm{R} 5)+$

$\mathrm{Q}(\mathrm{R} 5)+, \mathrm{R} 2$

Q $R 5$ T,$+ R 1$

\#AREA2, \#UFFSEI

BEQ PAR7

MOV R2, O\#AREA+2

MOV R1, O\#AREA+4

MOV \#AREA, RO

EMT $\quad 375$

BCS ERR

BR RETURN

PAR7: $\begin{array}{ll}\text { BIC } & R 1,(R 2) \\ & B R\end{array}$

[RR: CMPB \#O, A\#52

BEQ ERR 1

BR ERR2

ERR 1: .PRINT \#ERROR1

BR RETURN

ERR2: .PRINT \#ERROR2

RETURN: RTS PC ;RETURN

; $\quad$ ERROR MESSAGES

ÉRROR1: .ASCIZ $\langle 12\rangle\langle 15\rangle /$ ERROR: (BITCLR) NO OPERATOR PRIVILEGE FOR JOB $/\langle 12\rangle\langle 15\rangle$

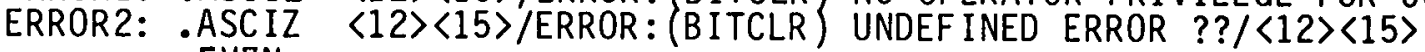
.EVEN

;SKIP ARGUMENT COUNT

;GET ADDRESS

;GET BITCLR VALUE

;PAR 7 MAPPED ?

;YES THEN PAR7

;MOVE ADDR TO EMT ARGUMENT AREA

;MUVE VALUE IO EMT ARGUMENT AREA

;POINT RO AT ARGUMENT AREA

;BRANCH ON ERROR

;RETURN

;CLEAR BITS

;DFTFRMINF. EMT ERROR

ARGIJMENT AREA FOR EMT'S

ÁREA: $\quad \begin{array}{ll}\text { BYYTE } & 4,140 \\ \text {.WORD } & 0\end{array}$

;ARGUMENT FOR BITCLR FIJNCTION

SAVE SPACE FOR ADDRESS

AREA2: WLRD 2 ;SAVE SPACE FOR VALUE

AREA2: .BLKW 2 ;EMT ARGUMENT BLOCK FOR .GVAL 


\section{-TITLE BITSET}

SUBROUTINE TO CLEAR BITS FROM A FORTRAN

PROGRAM UNDER TSX-PLUS.

FORTRAN CALL:

CALL BITSET (ADDRESS, VALUE)

.MCALL PRINT, . GVAL

OFFSET $=-10$

BITSET: TS

MOV

MOV

-GVAL \#AREA2, \#OFFSET

CMP

BEQ

MOV

$$
(\mathrm{R} 5)+
$$

Q $(R 5)+, R 2$

Q $(R 5)+, R 1$

;SKIP ARGUMENT COUNT

;GET ADDRESS

;GET BITSET VALUE

\#AREA2, \#OFFSET
RO, \#1

PAR7

;PAR 7 - MAPPED ?

;YES THEN PAR7

MOV

$R 2$, O\#AREA+2

;MOVE ADDR TO EMT ARGUMENT AREA

;MOVE VALUE TO EMT ARGUMENT AREA

MOV \#AREA,RO

EMT $\quad 375$

BCS ERR

BR RETURN

PAR7: BIS R1,(R2)

;POINT RO AT ARGUMENT AREA

;BRANCH ON ERROR

;RETURN

;SET BITS

ERR: CMPB

$B E Q$

RETURN

$\# 0$, $0 \# 52$

ERR 1

BR ERR2

ERR1: $\quad$.PRINT \#ERROR1

BR RETURN

ERR2: $\quad$.PRINT \#ERROR2

RETURN: RTS PC ;RETURN

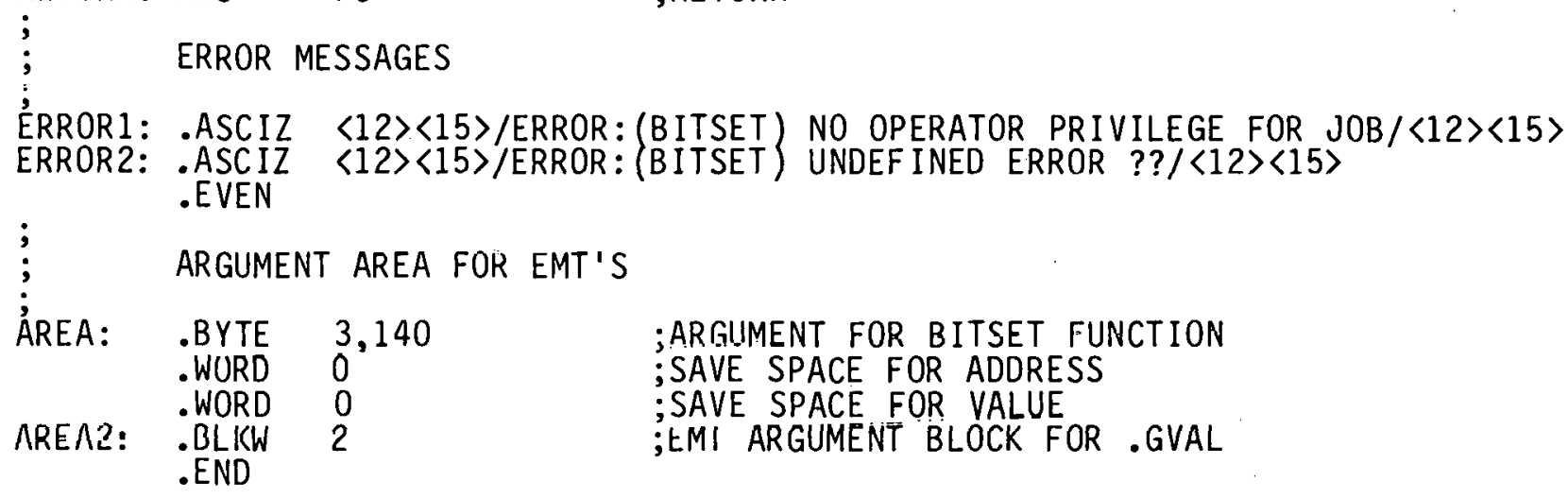


.TITLE IOPEEK

SUBROUTINE FOR TSX-PLUS TO REPLACE IPEEK

FORTRAN CALL:

$$
I=I \text { OPEEK (ADDRESS) }
$$

OR

CALL IOPEEK (ADDRESS, I)

.MCALL .PRINT, .GVAL

.GLOBL IOPEEK, IPEEK

OFFSET $=-10$

IOPEEK: .GVAL \#AREA2,\#OFFSET

CMP RO,\#1

PAR7

;PAR 7 MAPPED ?

;YES THEN PAR7

MOV $\quad(R 5)+, R 3$

MOV $\quad Q(R 5)+, R 2$

MOV R2, Q\#AREA+2

; GET ARGUMENT COUNT .

MOV \#AREA, RO

; GET ADDRESS

; MOVE ADDR TO EMT ARGUMENT AREA

; POINT RO AT ARGUMENT AREA

EMT $\quad 375$

BCS ERR

$\begin{array}{lll} & \text { BR } & \text { RETURN } \\ \text { PAR7: } & \text { JSR } & \text { PC,IPEEK }\end{array}$

$\begin{array}{lll} & \text { BR } & \text { EXIT } \\ \text { ERR: } & \text { CMPB } & \text { \#0, O\#52 } \\ & \text { BEQ } & \text { ERR1 } \\ & \text { BR } & \text { ERR2 } \\ \text { ERR1: } & \text {.PRINT } & \text { \#ERROR1 } \\ & \text { BR } & \text { RETURN } \\ \text { ERR2: } & \text {.PRINT } & \text { \#ERROR2 }\end{array}$

RETURN : CMP

$$
\text { BNE }
$$

; BRANCH ON ERROR

;RETURN

;CALL SYSLIB IPEEK

;UETERMINE EMT ERROR

EXIT: $\quad$ RTS

R3,\#2

$\mathrm{RU}$, IO(R5)

;SUBROUTINE CALL ?

;NO THEN EXIT

;YES THEN STORE RESULT

ERROR MESSAGES

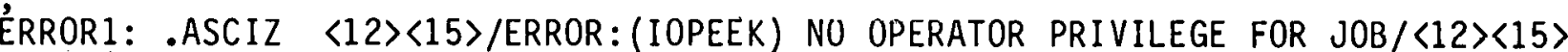

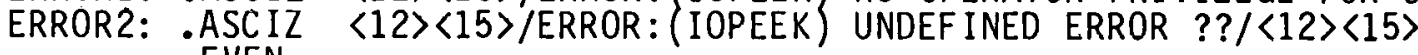
.EVEN

ARGUMENT AREA FOR EMT'S

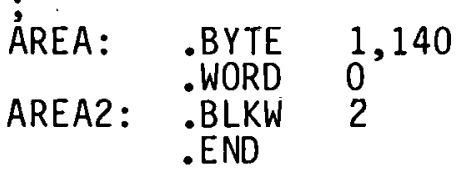

;EMT ARGUMENT FOR PEEK FUNCTION

;SAVE SPACE FOR ADDRESS

;EMT ARGUMENT BLOCK FOR .GVAL 
- TITLE IOPOKE
SUBROUTINE FOR TSX-PLUS TO REPLACE IPOKE

FORTRAN CALL:

CALL IOPOKE (ADDRESS, VALUE)

.MCALL .PRINT, .GVAL

.GLOBL IOPOKE,IPOKE

OFFSET $=-10$

IOPOKE: .GVAL \#AREA2, \#OFFSET

$\begin{array}{ll}\text { CMP } & \text { RO,\#1 } \\ \text { BEQ } & \text { PAR7 } \\ \text { TST } & \text { (R5)+ } \\ \text { MOV } & \text { Q(R5)+, R2 } \\ \text { MOV } & \text { Q R5 +, R1 } \\ \text { MOV } & \text { R2, Q\#AREA+2 } \\ \text { MOV } & \text { R1, Q\#AREA+4 } \\ \text { MOV } & \text { \#AREA, RO } \\ \text { EMT } & 375 \\ \text { BCS } & \text { ERR } \\ \text { BR } & \text { RETURN }\end{array}$

PAR7: JSR PC IPOKE

;PAR 7 MAPPED ?

;YES THEN PAR7

;SKIP ARGUMENT COUNT

;GET ADDRESS

;GET POKE VALUE

;MOVE ADDR TO EMT ARGUMENT AREA

;MOVE VALUE TO EMT ARGUMENT AREA

;POINT RO AT ARGUMENT AREA

;BRANCH ON ERROR

;RETURN

;CALL SYSLIB IPOKE

ERR: $\quad$ BR $\quad$ RETURN

;DETERMINE EMT ERROR

ERR 1: $\quad$.PRINT \#ERROR 1

BR RETURN

ERR2: .PRINT \#ERROR2

RETURN: RTS PC ;RETURN

; $\quad$ ERROR MESSAGES

ERROR 1: .ASCIZ $\langle 12\rangle\langle 15\rangle /$ ERROR: (IOPOKE) NO OPERATOR PRIVILEGE FOR JOB $/\langle 12\rangle\langle 15\rangle$

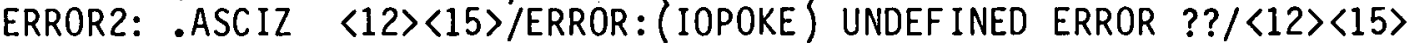
.EVEN

; $\quad$ ARGUMENT AREA FOR EMT'S

ÁREA: $\quad$ BYTE 2,140

$\begin{array}{ll}\text {.WORD } & 0 \\ \text {.WORD } & 0\end{array}$

;EMT ARGUMENT FOR POKE FUNCTION

;SAVE SPACE FOR ADDRESS

;SAVE SPACE FOR VALUE

AREA2: .BLKW 2 ;EMT ARGUMENT BLOCK FOR .GVAL 
-TITLE MAPIO

SUBROUTINE TO MAP I/O PAGE (PAR 7) TO A JOB'S

VIRTUAL ADDRESS REGION.

FORTRAN CALL:

CALL MAPIO

.MCALL .PRINT, . GVAL

-GLORL MAPIO

OFFSET $=-10$

MAPI0: .GVAL \#AREA2, \#OFFSET

$\begin{array}{lll}\text { ¿GVAL } & \text { \#AREA2, \#OFFSET } & \\ \text { CMP } & \text { RO,\#1 } & \text {;PAR 7 MAPPED ? } \\ \text { BEQ } & \text { PAR7 } & \text {;YES THEN PAR7 } \\ \text { MOV } & \text { \#AREA,R0 } & \\ \text { EMT } & 375 & \\ \text { BCS } & \text { ERR } & \text {;BRANCH ON ERROR } \\ \text { BR } & \text { RETURN } & \text {;RETURN } \\ \text { CMPB } & \text { \#0, O\#52 } & \text {;DETERMINE EMT ERROR } \\ \text { BEQ } & \text { ERR1 } & \\ \text { BR } & \text { ERR2 } & \end{array}$

ERR 1: $\quad$ PRINT \#ERROR I

$\begin{array}{lll} & \text { BR } & \text { RETURN } \\ \text { ERR2: } & \text {.PRINT } & \text { \#ERROR2 }\end{array}$

RETURN: RTS PC ;RETURN

ERROR MESSAGES

ÉRROR1: .ASCIZ $\langle 12\rangle\langle 15\rangle /$ ERROR: (MAPIO) NO UPLKATOR PRIVILEGE FOR JOB $/\langle 12\rangle\langle 15\rangle$

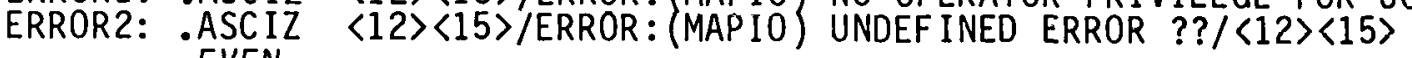
. EVEN

ARGUMENT AREA FOR EMT 375

ÁREA: .BYTE $5,140 \quad$;ARGUMENT FOR MAFIO FUNCTION

AREA2: .BLKW 2, ;EMT ARGUMENT AREA FOR .GVAL 
-TITLE UNMAP

SUBROUTINE TO UNMAP I/O PAGE (PAR 7) AND MAP

SIMULATED RMON TO JOB'S VIRTUAL ADDRESS REGION.

FORTRAN CALL:

CALL UNMAP

.MCALL .PRINT, .GVAL

.GLOBL UNMAP

OFFSET $=-10$

UNMAP: .GVAL \#AREA2,\#OFFSET

CMP RO,\#1 ;PAR 7 MAPPED?

BNE RETURN

MOV \#AREA, RO

;NO THEN RETURN

EMT $\quad 375$

BCS ERR

BR RETURN

ERR: $\quad$ CMPB \#0, @\#52

;BRANCH ON ERROR

;RETURN

;DETERMINE EMT ERROR

BEQ ERR1

ERR 1: $\quad$.PRINT \#ERROR 1

PRINT \#ERROR
BR RETURN

ERR2: $\quad$.PRINT \#ERROR2

RETURN: RTS

PC

;RETURN

ERROR MESSAGES

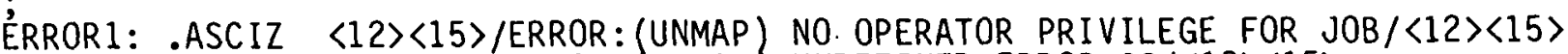

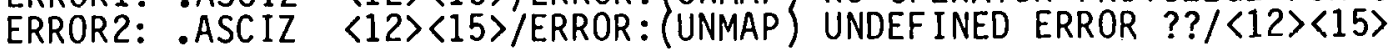
. EVEN

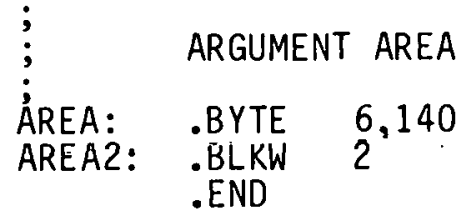

;ARGUMENT FOR UNMAP FUNCTIUNN ;EMT ARGUMENT AREA FOR . GVAL 
26

THIS PAGE

WAS INTENTIONALLY

LEFT BLANK 
Appendix B. Subroutines for control of program swapping

\author{
JLOCK \\ LOCKLO \\ UNLOCK
}




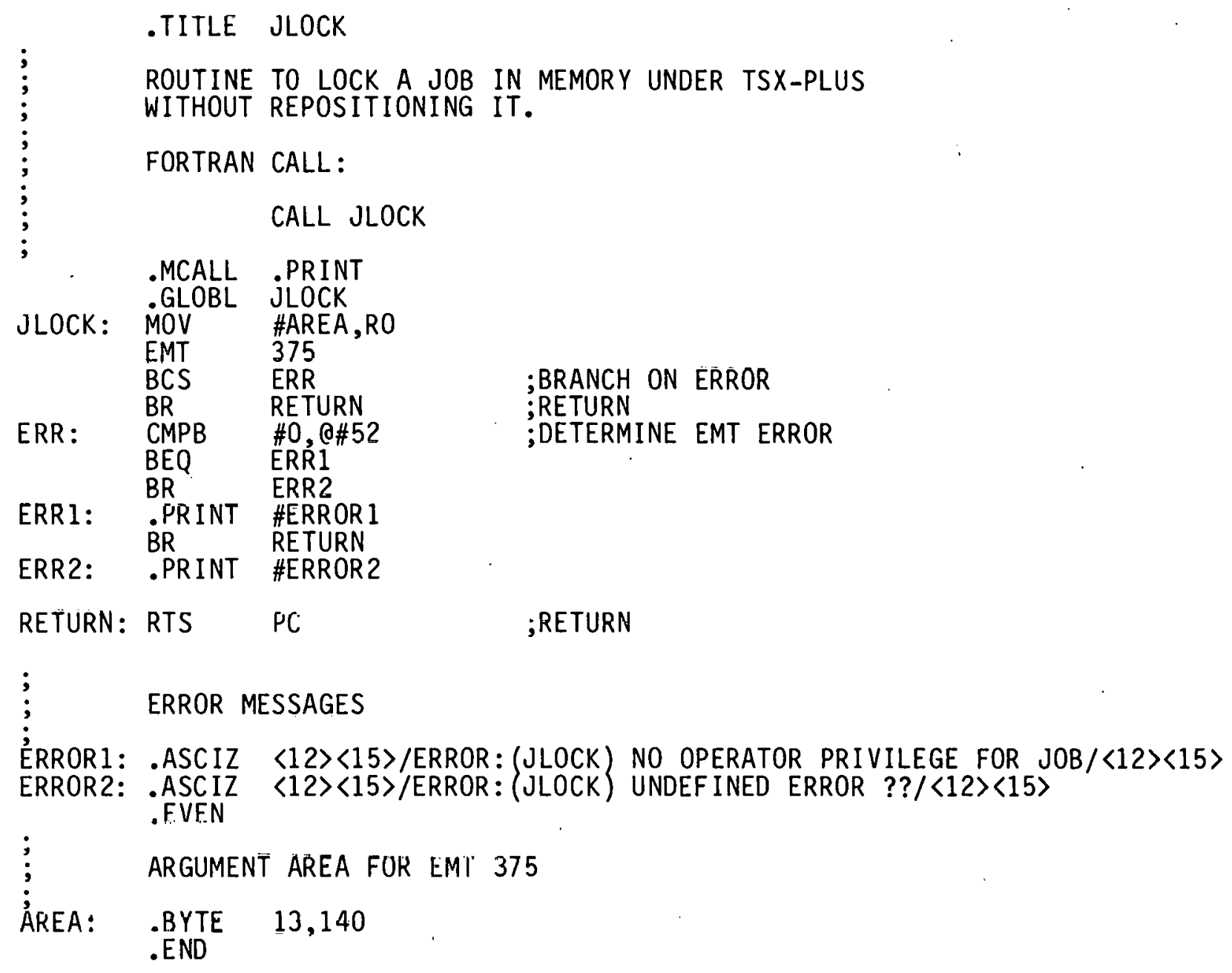




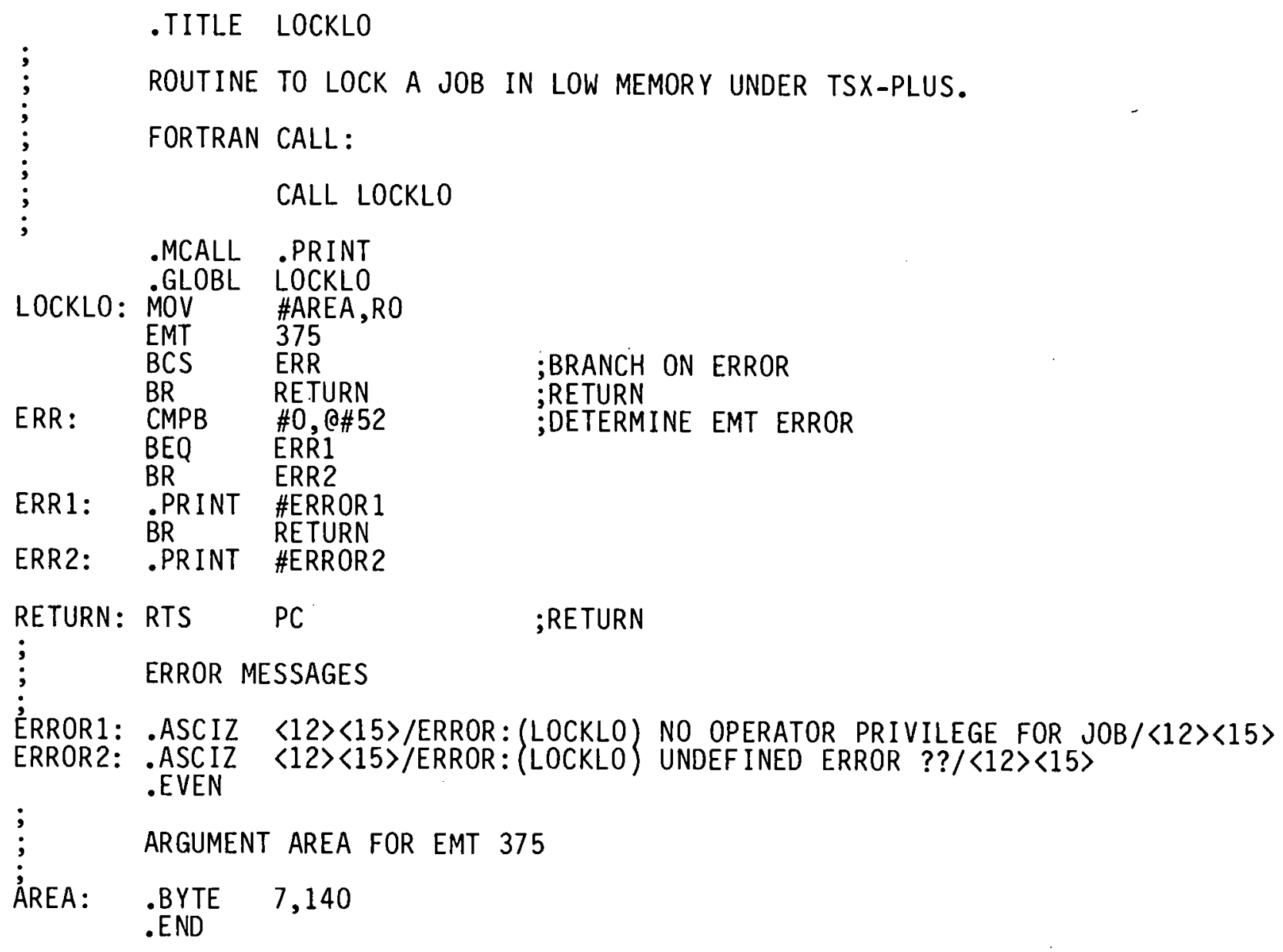




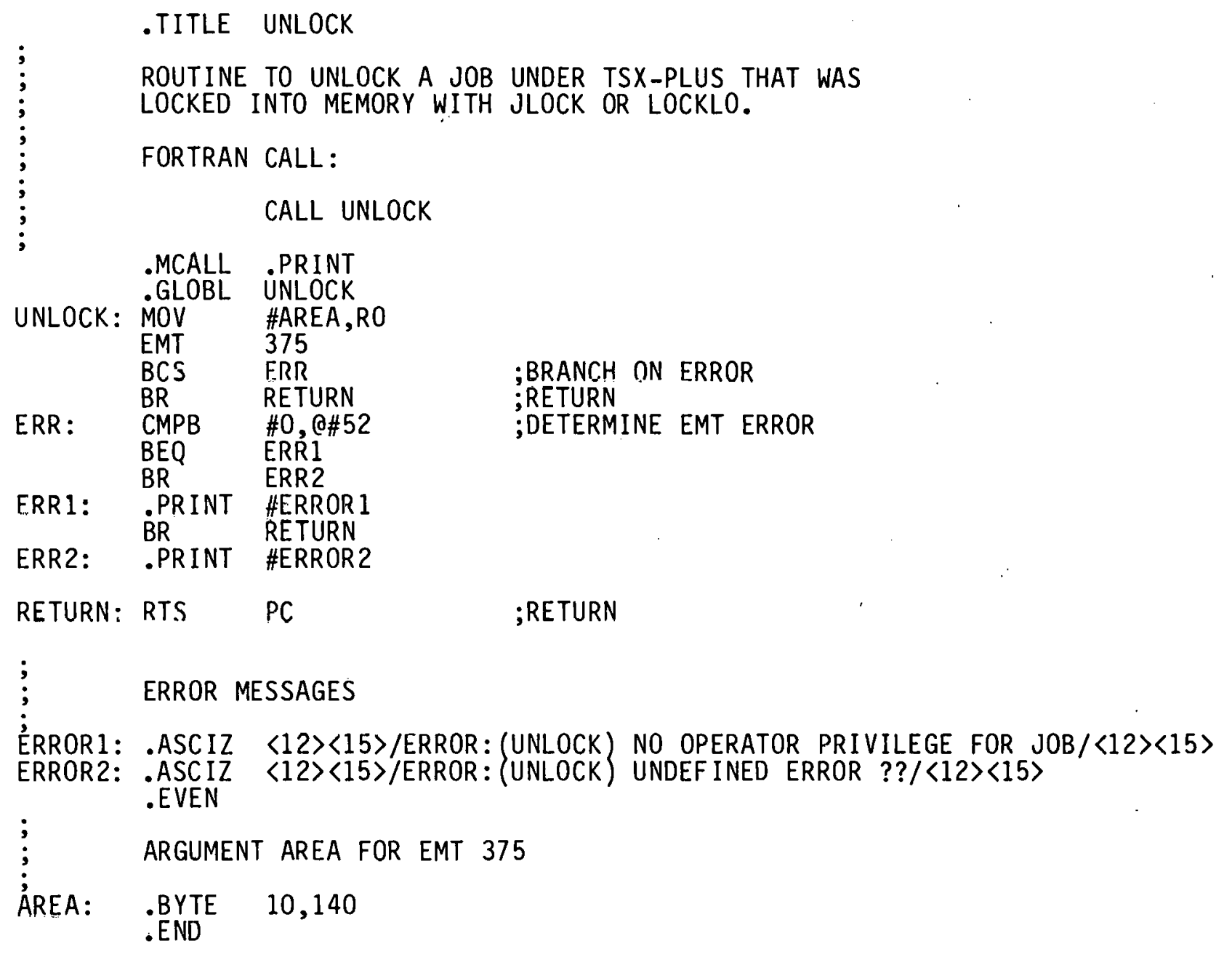


Appendix C. Subroutines for program communications

MSEND

MRECV

MRECVW 


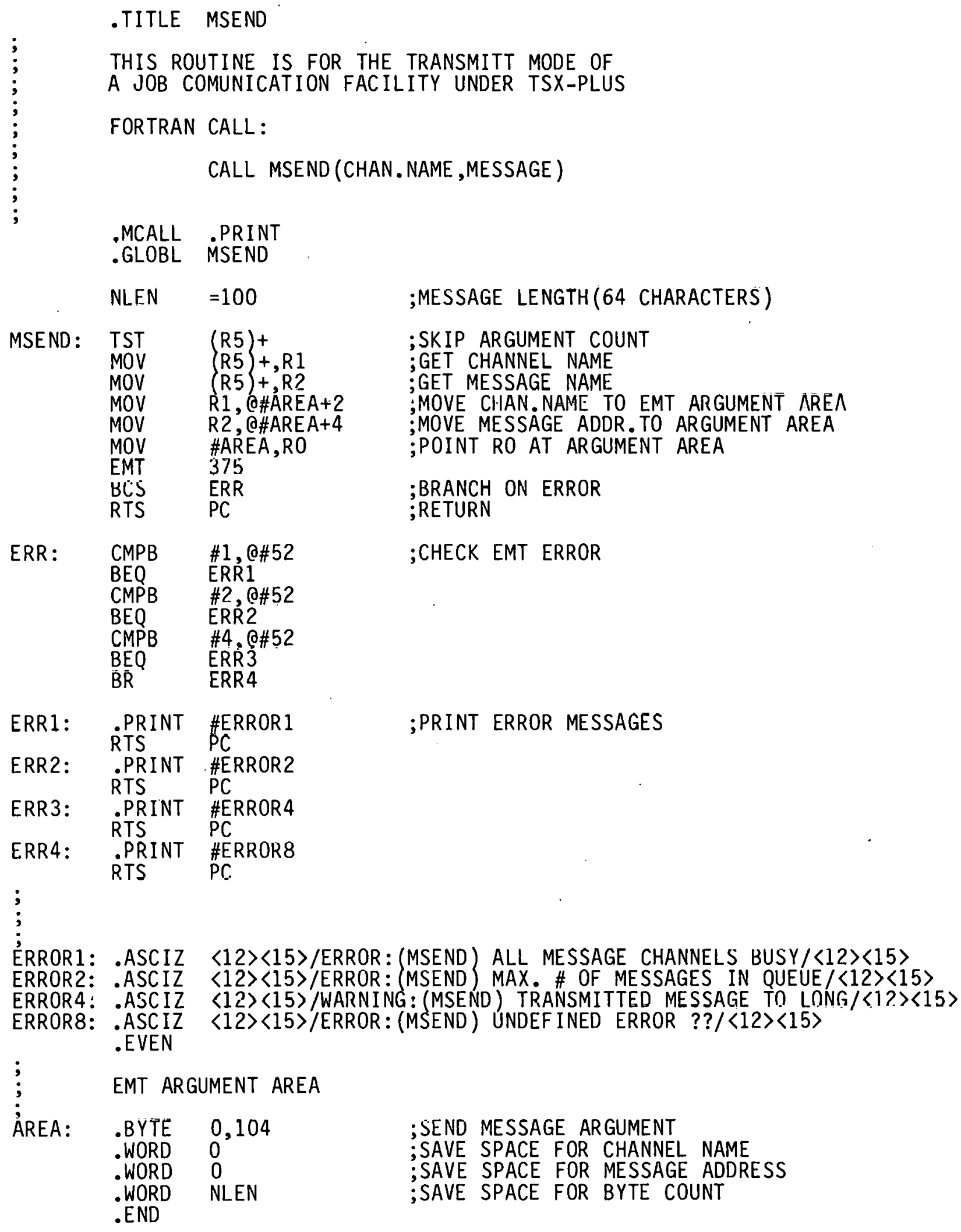




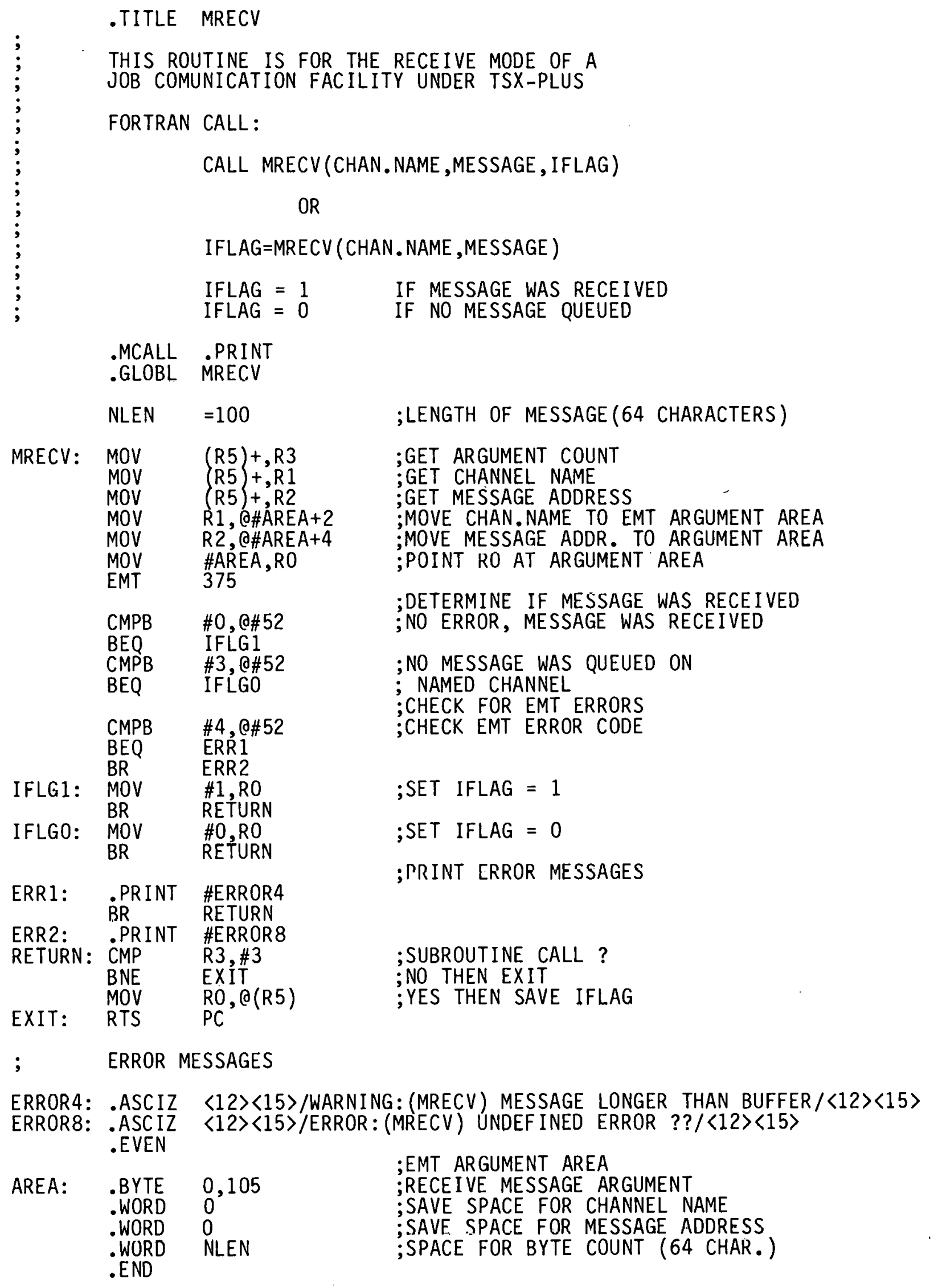


-TITLE MRECVW

THIS ROUTINE IS FOR THE RECEIVE MODE OF A

JOB COMUNICATION FACILITY UNDER TSX-PLUS

THIS ROUTINE WILL SUSPEND JOB EXECUTION

UNTIL THE MESSAGE IS RECEIVED.

FORTRAN CALL:

CALL MRECVW (CHAN. NAME, MESSAGE)

.MCALL .PRINT

-GLOBL MRECVW

NLEN $=100 \quad$;LENGTH OF MESSAGE (64 CHARACTERS)

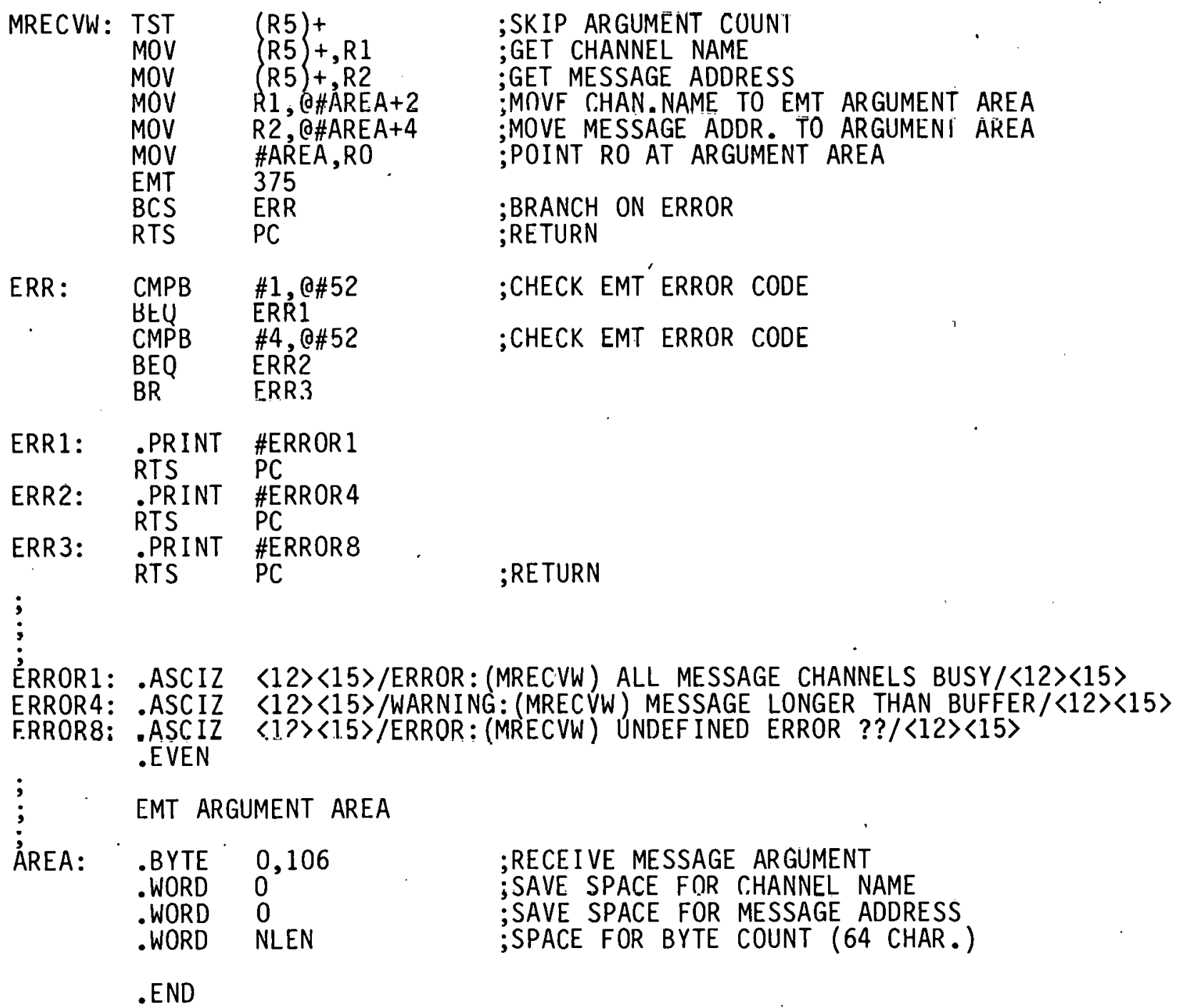


Appendix D. Subroutines for support of the TSX-Plus detached job facility

IDTACH

KILL 
-TITLE IDTACH.MAC

THIS ROUTINE IS FOR STARTING A DETACHED JOB UNDER TSX-PLUS

FORTRAN CALL:

CALL IDTACH(F ILENAME, JOB-NUMBER)

$\mathrm{OR}$

$J O B=I D T A C H(F I L E N A M E)$

FILENAME IS A COMMAND FILE THAT STARTS THE DESIRED

DETACHED JOB. THIS ROUTINE ALSO RETURNS THE JOB NUMBER. WARNING: A DETACHED JOB DOES NOT ASSUME. THE LOGICAL DEVICE ASSIGNMENTS OF THE USER.

USE PHYSICAL DEVICE ASSIGNMENTS:

JOB =IDTACH ('DYO:FILNAM.EXT')

FOR EXAMPLE DO NOT USE DK.:

DEFAULT .EXT IS .COM

-MCALL .PRINT

.GLOBL IDTACH

IDTACH : MOV

MOV

MOV

MOV

EMI

$\mathrm{BCS}$

$B R$

$(R 5)+, R 3$

;GET ARGUMENT COUNT

;GET ADDRESS OF F ILENAME

R1, O\#AREA+2

\#AREA, RO

375

ERR

RETURN

;MOVE FILENAME TO ARGUMENT AREA

;POINT RO AT ARGUMENT AREA

;BRANCH ON ERROR

;RETURN

ERR: CMPB \#1, @\#52

BEQ ERR1

;DETERMINE EMT ERROR

ERR1: .PRINT \#ERROR I

$\begin{array}{ll}\text { BPRINT \#ERROR } \\ \text { BR } & \text { RETURN }\end{array}$

ERR2: $\quad$ PRINT \#ERROR2

RETURN: CMP R3,\#2

BNE EXIT

$\begin{array}{ll}\text { MOV } & \text { RO, O(RE) } \\ \text { RTS } & \text { PC. }\end{array}$

;SUBROUIINE CALL ?

;NO THEN EXIT

;STORE RESULT

EXIT: RTS

;RETURN

ERROR MESSAGES

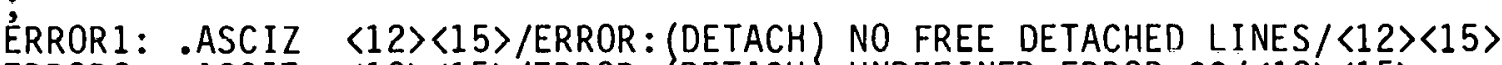

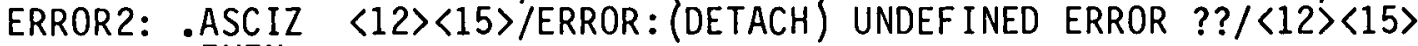
- EVEN

EMT ARGUMENT AREA

ÁREA: $\quad$ BYYTE 0,132

. WORD

;SAVE SPACE FOR FILNAME 
-TITLE KILL.MAC

- THIS ROUTINE KILLS A DETACHED JOB RUNNING UNDER TSX-PLUS. FORTRAN CALL:

CALL KILL (JOB-NUMBER)

.MCALL .PRINT

-GLOBL KILL

KILL: TST (R5)+

;SKIP ARGUMENT COUNT

MOV $\quad$ O(R5) +, R1 ;GET JOB-NUMBER

MOV RI, Q\#AREA+2 ;MOVE JOB \# TO ARGUMENT AREA

MOV \#AREA,RO ;POINT RO AT ARGUMENT AREA

EMT $\quad 375$

BCS ERR

RTS PC

;BRANCH ON ERROR ;RETURN

ERR: CMPB \#1,@\#52 ;DETERMINE EMT ERROR

BEQ ERR1

ERR1: $\quad$ BR 1 PRINT \#ERROR 1

$\begin{array}{lll} & \text { RTS } & \text { PC } \\ \text { ERR2: } & \text {.PRINT } & \text { \#ERROR2 } \\ & \text { RTS } & \text { PC }\end{array}$

; $\quad$ ERROR MESSAGES

ÉRROR 1: .ASCIZ $\langle 12\rangle\langle 15\rangle /$ ERROR: (KILL) INVALID JOB-NUMBER $/\langle 12\rangle\langle 15\rangle$

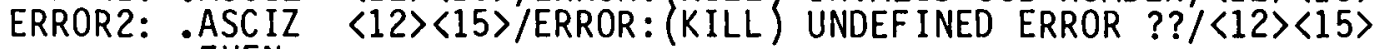
.EVEN

; EMT ARGUMENT AREA

ÁREA: .BYTE 2,132

-WORD

;SAVE SPACE FOR JOB-NUMBER 